\title{
Candidiasis and other oral mucosal lesions during and after interferon therapy for HCV-related chronic liver diseases
}

Yumiko Nagao ${ }^{1 *}$, Kouji Hashimoto ${ }^{2}$ and Michio Sata ${ }^{1,3+}$

\begin{abstract}
Background: Oral lichen planus (OLP) is seen frequently in patients with hepatitis $\mathrm{C}$ virus (HCV) infection. The aim of this study was to evaluate the occurrence of oral candidiasis, other mucosal lesions, and xerostomia during interferon (IFN) therapy for HCV infection.

Methods: Of 124 patients with HCV-infected liver diseases treated with IFN therapy in our hospital, 14 (mean age $56.00 \pm 12.94$ years) who attended to receive administration of IFN once a week were identified and examined for Candida infection and other oral lesions and for the measurement of salivary flow. Serological assays also were carried out.

Results: Cultures of Candida from the tongue surfaces were positive in 7 (50.0\%) of the 14 patients with HCV infection at least once during IFN therapy. C. albicans was the most common species isolated. The incidence of Candida during treatment with IFN did not increase above that before treatment. Additional oral mucosal lesions were observed in $50.0 \%$ (7/14) of patients: OLP in three (21.4\%), angular cheilitis in three (21.4\%) and recurrent aphthous stomatitis in one (7.1\%). OLP occurred in one patient before treatment with IFN, in one during treatment and in one at the end of treatment. $85.7 \%$ of the oral lesions were treated with topical steroids. We compared the characteristics of the 7 patients in whom Candida was detected at least once during IFN therapy (group 1) and the 7 patients in whom Candida was not detected during IFN therapy (group 2). The prevalence of oral mucosal lesions $(\mathrm{P}=0.0075)$ and incidence of external use of steroids $(\mathrm{P}=0.0308)$ in group 1 were significantly higher than in group 2. The average body weight of group 1 decreased significantly compared to group 2 ( $P=0.0088$ ). Salivary flow decreased in all subjects throughout the course of IFN treatment and returned at $6^{\text {th }}$ months after the end of treatment. In group 1, the level of albumin at the beginning of the $6^{\text {th }}$ month of IFN administration was lower than in group $2(\mathrm{P}=0.0550)$. According to multivariate analysis, one factor, the presence of oral mucosal lesions, was associated with the detection of Candida. The adjusted odds ratio for the factor was 36.00 ( $95 \%$ confidence interval 2.68-1485.94).
\end{abstract}

Conclusion: We should pay more attention to oral candidiasis as well as other oral mucosal lesions, in patients with weight loss during IFN treatment.

\footnotetext{
* Correspondence: nagao@med.kurume-u.ac.jp

${ }^{\dagger}$ Equal contributors

${ }^{1}$ Department of Digestive Disease Information \& Research, Kurume University

School of Medicine, 67 Asahi-machi, Kurume, Fukuoka 830-0011, Japan

Full list of author information is available at the end of the article
} 


\section{Background}

Hepatitis $\mathrm{C}$ is a major global public health problem and hepatitis $\mathrm{C}$ virus ( $\mathrm{HCV}$ ) infection is one of the main causes of cirrhosis and hepatocellular carcinoma (HCC). Interferon (IFN) therapy reduces the incidence of hepatocarcinogenesis in patients with hepatitis $\mathrm{C}$ and improves the long-term prognosis [1-4]. The standard therapy is a combination of pegylated interferon (Peg-IFN) and ribavirin (RBV). In addition, Peg-IFN, RBV, and telaprevir triple therapy is a new strategy expected to eradicate the $\mathrm{HCV}$ even in patients infected with difficult-to-treat genotype 1 strains, although adverse effects, such as anemia and rash, are frequent $[5,6]$.

Extrahepatic manifestations of $\mathrm{HCV}$ infection are numerous [7-10]. The most common diseases associated with $\mathrm{HCV}$ are hematologic, dermatologic, renal, and rheumatologic diseases.

Lichen planus (LP) is a chronic and mucocutaneous disease that can affect the oral mucosa, skin, genital mucosa, scalp and nails. A significant association between LP and chronic HCV infection has been reported in Japan, Italy, and Spain [11-16]. Previously, we reported that $\mathrm{HCV}$ was associated closely with extrahepatic manifestations such as oral LP (OLP) [12] and reported the examination of hepatitis $\mathrm{C}$ patients for oral lesions before, during and after IFN treatment $[17,18]$; OLP was seen in 11.7 (11/94)-16.7\% (4/24). OLP can occur, become exacerbated and persist during IFN treatment for hepatitis $C$, even when serum HCV RNA becomes negative. Our study suggested that OLP pathogenesis in hepatitis $C$ may be attributed to host factors induced by $\mathrm{HCV}$ infection, rather than direct pathological effects of the virus [17].

Candida generally causes no problems in healthy people. Candida is commonly cultured from oral mucosal lesions. Overgrowth of Candida, however, can lead to local discomfort, an altered taste sensation, dysphagia from esophageal overgrowth resulting in poor nutrition, slow recovery, and prolonged hospital stays [19]. Risk factors associated with symptomatic candidiasis include: local or systemic immunosuppression, haematological disorders, broad-spectrum antibiotic use, inhaled or systemic steroids, xerostomia, diabetes, wearing dentures, obturators and orthodontic appliances, and smoking [20-23]. Candida is has been reported to be found in $37.0 \%$ to $76.7 \%$ of OLP cases $[24,25]$. The treatment of OLP with steroids is known to lead to secondary yeast infection, which may complicate the treatment of OLP. C. albicans, C. glabrata and C. tropicalis have been isolated from OLP lesions treated with topical steroids [25].

Xerostomia is known as one of the adverse events observed during IFN therapy [26,27]. Aghemo et al. reported that dry mouth occurring during IFN therapy results from a reversible inhibition of salivary gland function and that RBV causes salivary gland hypofunction [27].
We also reported the salivary flow rate during IFN therapy $[18,28]$. In a Japanese Phase III trial of Peg-IFN alfa-2a and RBV involving 199 patients with chronic hepatitis C, including 99 patients with IFN treatment-naive genotype 1 and 100 patients with patients whom had not had a SVR after IFN therapy, $6.5 \%$ of all patients developed dry mouth. On the other hand, in a Japanese Phase III trial of Peg-IFN alfa-2b and RBV involving 332 chronic hepatitis $C$ patients, including 269 patients for 48 weeks treatment duration with genotype $1 \mathrm{~b}$ and high virus load, and 63 patients for 24 weeks treatment duration with others, $15.6 \%$ of all patients developed dry mouth.

There have been few reports on oral Candida before, during and after IFN treatment for chronic hepatitis C patients. The aims of this study were to determine the incidence of Candida as well as the development of OLP, angular cheilitis, recurrent aphthous stomatitis, and xerostomia, in the course of IFN treatment of patients with chronic hepatitis $\mathrm{C}$.

\section{Materials and methods Patients}

A total of 124 consecutive $\mathrm{HCV}$-infected patients for whom IFN therapy was planned had checkups for oral mucosal diseases, based on our hospital's clinical pathway in the Digestive Diseases Center at Kurume University Hospital Japan from July 30, 2008 to October 28, 2009. In this Digestive Diseases Center, physicians, surgeons, radiologists and an oral surgeon examine each patient in their own specialized area.

Seventeen of 124 patients agreed to the simultaneous consultation of the hepatologist and oral surgeon in our Digestive Diseases Center in order to receive administration of Peg-IFN and an oral examination once per week. The other 107 patients did not consult a doctor every week. Fourteen patients completed therapy. Three patients discontinued IFN treatment because of null-response. Systemic autoimmune disorders such as autoimmune hepatitis, and Sjögren's syndrome were considered as exclusion criteria for IFN therapy.

The 14 patients, 3 men and 11 women, who completed IFN therapy were examined. They ranged in age from 25 to 70 years, with an average age of $56.00 \pm 12.94$ years. Eleven patients with HCV genotype 1 received administration of Peg-IFN/RBV for 48-72 weeks. Two patients with HCV genotype 2 received administration of Peg-IFN/RBV for 24 weeks, and one patient with liver cirrhosis (HCV genotype 2) received administration of IFN beta for 24 weeks.

\section{Methods}

\section{Examination of oral mucosal disease}

We questioned the subjects about their frequency of tooth-brushing. We used the headband fiber (50-100-10, 
Daiichi Medical Co., Ltd.) with a brightness of 34,000 luces for mucosal examination. Oral biopsy was performed on some patients. The diagnosis of OLP was made on the basis of clinical and/or histopathological features. All patients were examined before IFN therapy, at the beginning of the $2^{\text {nd }}$ week of IFN administration, at the beginning of the $3^{\text {rd }}$ month of IFN administration, at the beginning of the $6^{\text {th }}$ month of IFN administration, at the end of IFN therapy, and at $6^{\text {th }}$ months after the end of treatment. The patients were weighed at each hospital visit. When a patient complained of haphalgesia and a burning sensation from oral musocal lesions, we prescribed external steroids, such as $0.1 \%$ Dexamethasone (Dexaltin ${ }^{\circledR}$ Nippon Kayaku Co., Ltd, Tokyo, Japan), Triamcinolone acetonide (Aphthaseal ${ }^{\circledR}$ Taisho Toyama Pharmaceutical Co., Ltd, Tokyo, Japan), and Beclometasone dipropionate (Salcoat ${ }^{\circledR}$ Teijin Pharma Co., Ltd, Tokyo, Japan).

\section{Salivary flow}

Salivary flow was measured in all patients. We used a simple and low-cost test for detection of xerostomia and this required chewing on a piece of gauze for $2 \mathrm{~min}$. A salivary flow rate of below $2 \mathrm{~g} / 2$ min was judged as decreased salivary secretion. All patients were examined before IFN therapy, at the beginning of the $2^{\text {nd }}$ week of IFN administration, at the beginning of the $3^{\text {rd }}$ month of IFN administration, at the beginning of the $6^{\text {th }}$ month of IFN administration, at the end of IFN therapy, and at $6^{\text {th }}$ months after the end of treatment.

\section{Candida isolation}

We examined Candida species on the surface of the tongue in 14 patients with chronic liver diseases before, during, and after IFN therapy. The surface of the tongue was rubbed ten times with cotton swabs and these were placed on CHROMagar Candida slants. CHROMagar Candida medium (CHROMagar, Paris, France) was prepared according to the manufacturer's instructions. The swab was inoculated into CHROMagar Candida medium by rotating the swab head on the surface of the medium. The plates were incubated at $35^{\circ} \mathrm{C}$ for $48 \mathrm{~h}$. Colony morphology and colour description were assigned in a standard manner by a single investigator.

When a patient diagnosed with candidiasis complained of a burning sensation in the oral cavity, we administered an antifungal agent, such as Miconazole (Florid ${ }^{\circledR}$ Mochida Pharmaceutical Co., Ltd, Tokyo, Japan) and Itraconazole (Itrizole ${ }^{\circledR}$ Janssen Pharmaceutical K.K., Tokyo, Japan).

\section{Serological assays}

At each visit to our hospital for administration of IFN, the patients were tested for platelets (PLT), white blood cell (WBC), and hemoglobin $(\mathrm{Hb})$, and for the following liver function tests: serum alanine aminotransferase (ALT), aspartate aminotransferase (AST), lactate dehydrogenase (LDH), total bilirubin (T.Bil) and albumin (Alb). The presence of anti-SS-A and anti-SS-B antibodies in all patients was tested by using an enzymelinked immunosorbent assay (ELISA). The normal levels of anti-SS-A (SS-A/Ro(E)[S]; TFB, Ink, Japan) and antiSS-B (SS-B/La(E) $[\mathrm{S}]$; TFB, Ink, Japan) are less than $10 \mathrm{U} / \mathrm{mL}$, respectively.

\section{Evaluation of liver diseases}

HCV RNA was analyzed in serum by quantitative PCR assay (COBAS AMPLICOR HCV MONITOR v 2.0 Test, COBAS AmpliPrep/COBAS Taq-Man HCV Test, Roche Molecular Systems, New Jersey, US) [29,30]. HCV genotype was determined by polymerase chain reaction assay, using a mixture of primers for the subtype, as reported previously [31]. Ultrasonographic examination was performed on all patients in order to investigate the shape of the liver and lesions occupying the liver. Computed tomography and liver biopsy were performed on some patients. We used other possible predictors of progression of liver cirrhosis, including serum Alb, T.Bil, prothrombin time, and PLT.

\section{Ethical considerations}

This investigation was undertaken with the understanding and consent of each participating subject and has been conducted in full accordance with ethical principles of the World Medical Association Declaration of Helsinki. The Ethical Committee of Kurume University concluded that this study was not included in an ethic guideline because this study is a medical practice aimed for diagnosis and treatment.

\section{Statistical analysis}

All data are expressed as mean \pm standard error. Differences between the two groups were analyzed using the Mann-Whitney U test, Wilcoxon's test, and the Fisher's exact test. Differences were judged significant for $\mathrm{p}<0.05$ (two-tailed). Adjusted odds ratios were calculated using logistic regression analysis. All statistical analyses were conducted using JMP Version 6 (SAS Institute, Cary, NC, USA). The level of statistical significance was defined as 0.05 .

\section{Results}

Incidence of positive Candida cultures and development of oral mucosal lesions

Cultures of Candida from the tongue surfaces were positive in seven $(50.0 \%)$ of the 14 patients with $\mathrm{HCV}$ infection at least once during IFN therapy. Table 1 shows the association of the incidence of positive Candida 
Table 1 Characteristics of the subjects

\begin{tabular}{|c|c|c|c|c|c|c|c|c|c|c|c|}
\hline \multirow[t]{2}{*}{ No. } & \multirow[t]{2}{*}{ Age } & \multirow[t]{2}{*}{ Sex } & \multirow{2}{*}{$\begin{array}{l}\text { Liver } \\
\text { Diagnosis }\end{array}$} & \multirow{2}{*}{$\begin{array}{l}\text { HCV } \\
\text { genotype }\end{array}$} & \multirow{2}{*}{$\begin{array}{l}\text { HCV } \\
\text { RNA } \\
\text { level }\end{array}$} & \multirow[t]{2}{*}{ IFN } & \multirow[b]{2}{*}{$\begin{array}{l}\text { Before } \\
\text { IFN }\end{array}$} & \multirow[b]{2}{*}{$\begin{array}{l}\text { colony } \\
\text { (n) }\end{array}$} & \multirow[b]{2}{*}{$\begin{array}{l}2 \mathrm{~W} \text { after } \\
\text { IFN }\end{array}$} & \multirow[b]{2}{*}{$\begin{array}{l}\text { colony } \\
\text { (n) }\end{array}$} & \multirow[b]{2}{*}{$3 \mathrm{M}$ after IFN } \\
\hline & & & & & & & & & & & \\
\hline 1 & 70 & $\mathrm{~F}$ & $\mathrm{CH}-\mathrm{C}$ & $1 b$ & High & Peg-IFN/RBV & - & & - & & - \\
\hline \multirow[t]{3}{*}{2} & 52 & M & $\mathrm{CH}-\mathrm{C}$ & $1 b$ & High & Peg-IFN/RBV & + & & + & & + \\
\hline & & & & & & & C. albicans & 3 & C. albicans & 1 & C. albicans \\
\hline & & & & & & & OLP & & OLP & & OLP \\
\hline \multirow[t]{2}{*}{3} & 33 & $\mathrm{~F}$ & $\mathrm{CH}-\mathrm{C}$ & $1 b$ & High & Peg-IFN/RBV & + & & - & & - \\
\hline & & & & & & & C. albicans & 2 & & & \\
\hline 4 & 53 & $\mathrm{~F}$ & LC-C & $\begin{array}{l}\text { ND } \\
\text { (serogroup 2) }\end{array}$ & Low & IFN beta & - & & - & & - \\
\hline \multirow[t]{3}{*}{5} & 70 & $\mathrm{~F}$ & $\mathrm{CH}-\mathrm{C}$ & $2 a$ & High & Peg-IFN/RBV & + & & - & & + \\
\hline & & & & & & & C. albicans & 1 & & & C. albicans \\
\hline & & & & & & & & & & & C. parapsilosis \\
\hline 6 & 60 & $\mathrm{~F}$ & $\mathrm{CH}-\mathrm{C}$ & $2 a$ & High & Peg-IFN/RBV & - & & - & & - \\
\hline \multirow[t]{3}{*}{7} & 57 & $F$ & $\mathrm{CH}-\mathrm{C}$ & $1 b$ & High & Peg-IFN/RBV & + & & - & & + \\
\hline & & & & & & & C. albicans & 2 & & & C. albicans \\
\hline & & & & & & & & & & & $\begin{array}{l}\text { recurrent } \\
\text { aphthous } \\
\text { stomatitis }\end{array}$ \\
\hline 8 & 58 & $\mathrm{~F}$ & $\mathrm{CH}-\mathrm{C}$ & $1 b$ & High & Peg-IFN/RBV & - & & - & & - \\
\hline 9 & 25 & $\mathrm{~F}$ & $\mathrm{CH}-\mathrm{C}$ & $1 b$ & High & Peg-IFN/RBV & - & & - & & - \\
\hline 10 & 54 & $\mathrm{~F}$ & $\mathrm{CH}-\mathrm{C}$ & $1 b$ & High & Peg-IFN/RBV & - & & - & & - \\
\hline \multirow[t]{3}{*}{11} & 61 & $\mathrm{~F}$ & $\mathrm{CH}-\mathrm{C}$ & $1 b$ & High & Peg-IFN/RBV & + & & - & & + \\
\hline & & & & & & & C. albicans & 1 & & & C. albicans \\
\hline & & & & & & & & & & & $\begin{array}{l}\text { angular } \\
\text { cheilitis }\end{array}$ \\
\hline \multirow[t]{2}{*}{12} & 69 & $\mathrm{~F}$ & $\mathrm{CH}-\mathrm{C}$ & $1 b$ & High & Peg-IFN/RBV & + & & - & & + \\
\hline & & & & & & & C. albicans & 1 & & & C. albicans \\
\hline 13 & 60 & M & $\mathrm{CH}-\mathrm{C}$ & $1 b$ & High & Peg-IFN/RBV & - & & - & & - \\
\hline \multirow[t]{2}{*}{14} & 62 & M & $\mathrm{CH}-\mathrm{C}$ & $1 b$ & Low & Peg-IFN/RBV & - & & - & & - \\
\hline & & & & & & & & & & & OLP \\
\hline \multicolumn{4}{|c|}{$\begin{array}{l}\text { Incidence of Candida } \\
\text { or mucosal lesions (\%) }\end{array}$} & & & & $42.86 \%$ & & $7.14 \%$ & & $35.71 \%$ \\
\hline \multicolumn{4}{|c|}{ Total colonies (n) } & & & & & 10 & & 1 & \\
\hline \multicolumn{4}{|c|}{ C. albicans (the number of patients) } & & & & 6 & & 1 & & 5 \\
\hline \multicolumn{4}{|c|}{ C. parapsilosis (the number of patients) } & & & & 0 & & 0 & & 1 \\
\hline \multicolumn{4}{|c|}{ C. Iusitaniae (the number of patients) } & & & & 0 & & 0 & & 0 \\
\hline \multicolumn{4}{|c|}{ C. tropicalis (the number of patients) } & & & & 0 & & 0 & & 0 \\
\hline
\end{tabular}




\begin{tabular}{|c|c|c|c|c|c|c|c|c|c|}
\hline \multicolumn{8}{|c|}{ Candida } & \multirow{2}{*}{$\begin{array}{l}\text { Oral } \\
\text { mucosal } \\
\text { lesions }\end{array}$} & \multirow{2}{*}{$\begin{array}{l}\text { Study } \\
\text { group } \\
1 / 2\end{array}$} \\
\hline $\begin{array}{l}\text { colony } \\
\text { (n) }\end{array}$ & $\begin{array}{l}6 \mathrm{M} \\
\text { after } \\
\text { IFN }\end{array}$ & $\begin{array}{l}\text { colony } \\
\text { (n) }\end{array}$ & $\begin{array}{l}\text { end of } \\
\text { treatment }\end{array}$ & $\begin{array}{l}\text { colony } \\
\text { (n) }\end{array}$ & $\begin{array}{l}6 \mathrm{M} \text { after end } \\
\text { of treatment }\end{array}$ & $\begin{array}{l}\text { colony } \\
\text { (n) }\end{array}$ & $\begin{array}{l}\text { Detection } \\
\text { during } \\
\text { IFN therapy } \\
\text { (at least once) }\end{array}$ & & \\
\hline & - & & - & & - & & - & - & group 2 \\
\hline & + & & + & & + & & + & + & group 1 \\
\hline \multirow[t]{6}{*}{1} & C. albicans & 1 & C. albicans & 1 & C. albicans & 2 & & & \\
\hline & & & & & C. tropicalis & 1 & & & \\
\hline & OLP & & OLP & & OLP & & & & \\
\hline & - & & - & & - & & - & - & group 2 \\
\hline & - & & - & & - & & - & - & group 2 \\
\hline & + & & + & & - & & + & + & group 1 \\
\hline \multirow[t]{5}{*}{1} & C. albicans & 2 & C. albicans & 2 & & & & & \\
\hline & & & & & & & & & \\
\hline & angular cheilitis & & & & & & & & \\
\hline & - & & - & & - & & - & - & group 2 \\
\hline & + & & + & & + & & + & + & group 1 \\
\hline \multirow[t]{8}{*}{1} & C. albicans & 1 & C. albicans & 1 & C. albicans & 1 & & & \\
\hline & $\begin{array}{l}\text { recurrent aphthous } \\
\text { stomatitis }\end{array}$ & & $\begin{array}{l}\text { recurrent aphthous } \\
\text { stomatitis }\end{array}$ & & & & & & \\
\hline & + & & - & & - & & + & - & group 1 \\
\hline & C. albicans & 1 & & & & & & & \\
\hline & - & & - & & - & & - & - & group 2 \\
\hline & - & & - & & - & & - & + & group 2 \\
\hline & & & OLP & & OLP & & & & \\
\hline & + & & - & & - & & + & + & group 1 \\
\hline \multirow[t]{2}{*}{1} & C. albicans & 1 & & & & & & & \\
\hline & + & & + & & + & & + & + & group 1 \\
\hline \multirow[t]{7}{*}{1} & C. albicans & 1 & C. albicans & 1 & C. albicans & 1 & & & \\
\hline & angular cheilitis & & & & & & & & \\
\hline & - & & - & & - & & - & - & group 2 \\
\hline & - & & + & & - & & + & + & group 1 \\
\hline & & & C. Iusitaniae & 1 & & & & & \\
\hline & OLP & & OLP & & OLP & & & & \\
\hline & $42.86 \%$ & & $35.71 \%$ & & $21.43 \%$ & & $50.00 \%$ & $50.00 \%$ & \\
\hline \multirow[t]{5}{*}{6} & & 7 & & 6 & & 5 & & & \\
\hline & 6 & & 4 & & 3 & & & & \\
\hline & 0 & & 0 & & 0 & & & & \\
\hline & 0 & & 1 & & 0 & & & & \\
\hline & 0 & & 0 & & 1 & & & & \\
\hline
\end{tabular}

HCV, hepatitis C virus; $\mathrm{CH}-\mathrm{C}$, chronic hepatitis C; LC-C, liver cirrhosis type C; OLP, oral lichen planus; C., Candida; IFN, interferon; Peg-IFN, pegylated interferon; RBV, ribavirin; $M$, male; $F$, female; ND, not detected; -, negative; + , positive. 
cultures and IFN therapy. The incidence of positive Candida cultures was $42.86 \%$ (6 cases, C. albicans) before IFN therapy, $7.14 \%$ ( 1 case, C. albicans) at the beginning of the $2^{\text {nd }}$ week of IFN administration, 35.71\% (4 cases, C. albicans; 1 case, C. albicans and C. parapsilosis) at the beginning of the $3^{\text {rd }}$ month of IFN administration, $42.86 \%$ (6 cases, C. albicans) at the beginning of the $6^{\text {th }}$ month of IFN administration, $35.71 \%$ (4 cases, C. albicans; 1 case, C. lusitaniae) at the end of IFN therapy and 21.43\% (2 cases, C. albicans; 1 case, C. albicans and C. tropicalis) at $6^{\text {th }}$ months after the end of treatment. $C$. albicans was the most common species isolated from tongue surfaces. The incidence of Candida during treatment with IFN did not increase above that before treatment.

Oral mucosal lesions were observed in 50.00\% (7/14) of patients: three with OLP $(21.43 \%, 2$ men and 1 woman), three with angular cheilitis (21.43\%, 3 women) and one with recurrent aphthous stomatitis (7.14\%, 1 woman). OLP occurred in one patient before treatment with IFN, in one during treatment and in one at the end of treatment (Table 1). Patient no. 2 (a 52 year old male) had erosive OLP before IFN therapy; his lesions became exacerbated during IFN therapy but he was able to complete the therapy because of improvement with steroid application.

We administered antifungal agents to two patients (nos. 2 and 5 in Table 1) with candidiasis who complained of burning pain and prescribed external steroids for six patients (nos. 2, 5, 7, 10, 11, and 12 in Table 1) with oral mucosal lesions.

\section{Comparison between Candida positive and negative groups}

We compared the characteristics of the 7 patients (group 1) in whom Candida was detected at least once during IFN therapy and the 7 patients (group 2) in whom Candida was not detected during treatment (Table 2). The prevalence of oral mucosal lesions and incidence of external use of steroids were $85.71 \%(6 / 7)$ and $71.43 \%(5 / 7)$, respectively, in group 1 and 14.29\% $(1 / 7)$ and $14.29 \%(1 / 7)$, respectively, in group 2 . The prevalence of oral mucosal lesions $(\mathrm{P}=0.0075)$ and incidence of external use of steroids $(\mathrm{P}=0.0308)$ was significantly higher in group 1 than group 2 . The diagnosis of oral mucosal disease in group 1 included: OLP $(n=2)$, angular cheilitis $(\mathrm{n}=3)$, and recurrent aphthous stomatitis $(n=1)$. That in group 2 was OLP $(n=1)$.

Body weight decreased significantly in group 1 during IFN therapy, compared to group $2(\mathrm{P}=0.0088)$. Number of neutrophils, PLT, Alb, and $\mathrm{Hb}$ decreased in all subjects throughout the course of IFN treatment. In group 1, the level of Alb at the beginning of the $6^{\text {th }}$ month of IFN administration was lower than in group $2(\mathrm{P}=0.0550$, Table 2). The number of times teeth were brushed after every meal was lower in group 1 than group 2 .

\section{Salivary flow}

Salivary flow decreased in all subjects throughout the course of IFN treatment and returned at $6^{\text {th }}$ months after the end of treatment (Table 2). Salivary flow was $6.10 \pm$ $1.81 \mathrm{~g} / 2 \mathrm{~min}$ before IFN therapy, $5.71 \pm 2.60 \mathrm{~g} / 2 \mathrm{~min}$ at the beginning of the $2^{\text {nd }}$ week of IFN administration, $5.23 \pm 2.14 \mathrm{~g} / 2 \mathrm{~min}$ at the beginning of the $3^{\text {rd }}$ month of IFN administration, $5.42 \pm 1.97 \mathrm{~g} / 2 \mathrm{~min}$ at the beginning of the $6^{\text {th }}$ month of IFN administration, $5.31 \pm 2.06 \mathrm{~g} /$ $2 \mathrm{~min}$ at the end of IFN therapy and $6.02 \pm 1.81 \mathrm{~g} / 2 \mathrm{~min}$ at $6^{\text {th }}$ months after the end of treatment. There was no significant difference in the salivary flow between group 1 and group 2 .

\section{Multivariate analysis}

According to multivariate analysis, one factor, the presence of oral mucosal lesions, was associated with the detection of Candida. The adjusted odds ratio for the factor was 36.00 (95\% confidence interval 2.68-1485.94).

\section{Discussion}

Oral Candida albicans is known to have been isolated from patients with OLP [24,25]. Some Candida albicans isolates with special virulence attributes might be cofactors which contribute to the development of OLP, especially erosive OLP [32]. The erosive OLP can cause spontaneous pain during eating and tooth-brushing.

There have been few reports of the detection of oral Candida before, during and after IFN treatment for chronic hepatitis C. In this study, Candida was detected in $50.0 \%$ of patients with HCV-related chronic liver disease and who received IFN treatment. The most significant factor associated with Candida was the presence of oral mucosal lesions associated with IFN therapy. 85.71\% $(6 / 7)$ of the oral lesions were treated with topical steroids. We found no correlation between $\mathrm{HCV}$ genotype, levels of HCV RNA, IFN type, dose or administration schedule, or effect of IFN therapy with Candida detection.

Poor oral health has been reported in HCV-infected patients [33-36]. Coates et al. reported that the experience of dental caries was significantly worse in $\mathrm{HCV}$ infected subjects than in patients in general [33]. Griffin et al. found that patients with rheumatoid arthritis, diabetes or a liver condition were twice as likely to have an urgent need for dental treatment as patients who did not have these diseases and documented a high burden of unmet dental care needs among patients with chronic diseases [36]. The authors showed that HCV was the strongest predictor of patients reporting poor oral health. 
Table 2 Comparison between Candida positive and negative groups

\begin{tabular}{|c|c|c|c|c|c|}
\hline & & Total & Goup 1 & Group 2 & $P$ value \\
\hline Subjects (n) & & 14 & 7 & 7 & \\
\hline $\operatorname{Sex}(M / F)$ & & $3 / 11$ & $2 / 5$ & $1 / 6$ & NS \\
\hline Age (mean \pm SD) & & $56.00 \pm 12.94$ & $61.30 \pm 6.47$ & $50.71 \pm 16.00$ & NS \\
\hline \multirow[t]{3}{*}{ HCV genotype } & $1 b$ & $11(78.57 \%)$ & $6(85.71 \%)$ & $5(71.43 \%)$ & NS \\
\hline & $2 \mathrm{a}$ & $2(14.29 \%)$ & $1(14.29 \%)$ & $1(14.29 \%)$ & NS \\
\hline & ND (serotype 2) & $1(7.14 \%)$ & $0(0 \%)$ & $1(14.29 \%)$ & NS \\
\hline \multirow[t]{2}{*}{ HCV RNA level } & High & $12(85.71 \%)$ & $6(85.71 \%)$ & $6(85.71 \%)$ & NS \\
\hline & Low & $2(14.29 \%)$ & $1(14.29 \%)$ & $1(14.29 \%)$ & NS \\
\hline Weight loss during IFN therapy & & $5.69 \pm 4.57$ & $8.71 \pm 2.81$ & $2.66 \pm 4.00$ & 0.0088 \\
\hline \multirow[t]{6}{*}{ Neutrophil count $(\mu / L)$} & Before IFN & $2546.11 \pm 793.47$ & $2481.34 \pm 599.67$ & $2610.89 \pm 997.36$ & NS \\
\hline & 2 weeks after IFN & $1229.11 \pm 590.25$ & $1260.51 \pm 473.58$ & $1197.70 \pm 726.82$ & NS \\
\hline & 3 months after IFN & $1343.05 \pm 584.48$ & $1636.51 \pm 670.69$ & $1049.59 \pm 298.98$ & NS \\
\hline & 6 months after IFN & $1319.11 \pm 301.15$ & $1442.69 \pm 194.15$ & $1195.53 \pm 350.95$ & NS \\
\hline & End of treatment & $1360.21 \pm 547.74$ & $1420.54 \pm 401.41$ & $1299.87 \pm 693.13$ & NS \\
\hline & 6 months after treatment & $2349.21 \pm 695.36$ & $2578.63 \pm 716.47$ & $2119.80 \pm 641.48$ & NS \\
\hline \multirow[t]{6}{*}{$\mathrm{PLT}(\times 10-4 / \mu \mathrm{L})$} & Before IFN & $17.58 \pm 7.06$ & $17.54 \pm 3.32$ & $17.61 \pm 9.84$ & NS \\
\hline & 2 weeks after IFN & $14.04 \pm 7.28$ & $14.37 \pm 4.70$ & $13.71 \pm 9.61$ & NS \\
\hline & 3 months after IFN & $13.69 \pm 6.08$ & $14.27 \pm 5.36$ & $13.11 \pm 7.12$ & NS \\
\hline & 6 months after IFN & $13.20 \pm 5.31$ & $14.21 \pm 4.72$ & $12.19 \pm 6.03$ & NS \\
\hline & End of treatment & $14.45 \pm 5.05$ & $14.50 \pm 4.59$ & $14.40 \pm 5.84$ & NS \\
\hline & 6 months after treatment & $16.86 \pm 6.03$ & $18.14 \pm 4.29$ & $15.59 \pm 7.52$ & NS \\
\hline \multirow[t]{6}{*}{$\mathrm{Hb}(\mathrm{g} / \mathrm{dL})$} & Before IFN & $13.97 \pm 1.08$ & $13.91 \pm 1.26$ & $14.03 \pm 0.97$ & NS \\
\hline & 2 weeks after IFN & $13.04 \pm 1.06$ & $13.33 \pm 1.34$ & $12.76 \pm 0.67$ & NS \\
\hline & 3 months after IFN & $10.94 \pm 1.55$ & $10.40 \pm 1.57$ & $11.47 \pm 1.45$ & NS \\
\hline & 6 months after IFN & $10.61 \pm 1.73$ & $9.81 \pm 1.45$ & $11.41 \pm 1.70$ & NS \\
\hline & End of treatment & $10.99 \pm 1.74$ & $10.23 \pm 1.89$ & $11.74 \pm 1.27$ & NS \\
\hline & 6 months after treatment & $13.29 \pm 1.48$ & $12.99 \pm 2.05$ & $13.59 \pm 0.58$ & NS \\
\hline \multirow[t]{6}{*}{ Alb $(g / d L)$} & Before IFN & $4.18 \pm 0.35$ & $4.10 \pm 0.34$ & $4.26 \pm 0.36$ & NS \\
\hline & 2 weeks after IFN & $3.76 \pm 0.48$ & $3.75 \pm 0.38$ & $3.76 \pm 0.59$ & NS \\
\hline & 3 months after IFN & $3.84 \pm 0.37$ & $3.76 \pm 0.45$ & $3.92 \pm 0.28$ & NS \\
\hline & 6 months after IFN & $3.88 \pm 0.33$ & $3.74 \pm 0.42$ & $4.02 \pm 0.12$ & 0.0550 \\
\hline & End of treatment & $3.90 \pm 0.38$ & $3.77 \pm 0.35$ & $4.03 \pm 0.39$ & NS \\
\hline & 6 months after treatment & $4.27 \pm 0.35$ & $4.23 \pm 0.34$ & $4.30 \pm 0.39$ & NS \\
\hline \multirow[t]{6}{*}{ Salivary flow (g/2 min) } & Before IFN & $6.10 \pm 1.81$ & $5.86 \pm 1.90$ & $6.38 \pm 1.81$ & NS \\
\hline & 2 weeks after IFN & $5.71 \pm 2.60$ & $5.88 \pm 2.33$ & $5.55 \pm 3.03$ & NS \\
\hline & 3 months after IFN & $5.23 \pm 2.14$ & $4.92 \pm 2.34$ & $5.53 \pm 2.06$ & NS \\
\hline & 6 months after IFN & $5.42 \pm 1.97$ & $5.32 \pm 2.14$ & $5.51 \pm 1.94$ & NS \\
\hline & End of treatment & $5.31 \pm 2.06$ & $5.33 \pm 1.58$ & $5.30 \pm 2.58$ & NS \\
\hline & 6 months end of IFN & $6.02 \pm 1.81$ & $6.03 \pm 1.38$ & $6.00 \pm 2.28$ & NS \\
\hline Diabetes mellitus & positive, n (\%) & $2(14.29 \%)$ & $1(14.29 \%)$ & $1(14.29 \%)$ & NS \\
\hline Oral mucosal lesions & positive, n (\%) & $7(50.00 \%)$ & $6(85.71 \%)$ & $1(14.29 \%)$ & 0.0075 \\
\hline Steroid for external use & positive, $\mathrm{n}(\%)$ & $6(42.86 \%)$ & $5(71.43 \%)$ & $1(14.29 \%)$ & 0.0308 \\
\hline Tooth-brushing after every meal & yes, n (\%) & $8(57.14 \%)$ & $3(42.86 \%)$ & $5(71.43 \%)$ & NS \\
\hline Denture wearer & yes, n (\%) & $0(0 \%)$ & $0(0 \%)$ & $0(0 \%)$ & NS \\
\hline Administration of antifungal agent & yes, n (\%) & $2(14.29 \%)$ & $2(28.57 \%)$ & $0(0 \%)$ & NS \\
\hline Effect of IFN therapy & SVR, n (\%) & $11(78.57 \%)$ & $6(85.71 \%)$ & $5(71.43 \%)$ & NS \\
\hline
\end{tabular}

HCV, hepatitis C virus; IFN, interferon; M, male; F, female; ND, not detected; NS, not significant; PLT, platelets; Hb, hemoglobin; Alb, albumin. 
In our study, there was a high rate of detection of candida species in patients who did not brush their teeth after every meal, compared to those who did so. Oral hygiene should be encouraged in patients during IFN treatment.

In our previous study, dental problems delayed the initiation of IFN therapy for up to 105 days [28]. HCVinfected patients treated with IFN should be managed by intensive oral care because of lower resistance to infection during the therapy. With regard to the painful OLP, it is just conceivable that an oral cavity with $\mathrm{HCV}$ infection is likely to become less healthy than one without HCV infection. REFRECARE- ${ }^{\circledR}$ (EN Otsuka Pharmaceutical Co. Ltd. Iwate, Japan) is an oral care gel containing hinokitiol, which can remove stains on the teeth and general oral debris, and is effective in the prevention of breath odor and gum diseases. Hinokitiol has significant antimicrobial efficacy against Staphylococcus aureus, Propionibacterium acnes, coronavirus, Trichophyton, and Candida albicans [37]. We reported that this oral care gel improved the subjective symptoms of all patients with OLP [38].

IFN therapy for $\mathrm{HCV}$ infection is associated with various side effects, including a greater level of fatigue, loss of appetite, weight loss, sleep problems, and depression. In the present study, weight loss during IFN therapy lead to oral candidiasis. Weight loss is considered to be the important risk factor for oral candidiasis. Back-Brito GN et al. demonstrated that eating disorders can lead to an increased oral Candida carriage [39].

Our study showed that hypoalbuminemia during IFN therapy might lead to oral candidiasis. We reported previously a strong association between hypoalbuminemia and mortality in a hyperendemic area (X town) of HCV infection in Japan [40] and that hypoalbuminemia was an independent risk factor for the development of OLP [41].

Several studies have shown an association between HCV and Sjögren's symdrome (SS) [42,43]. In this study, we demonstrated that the salivary flow of all patients with $\mathrm{HCV}$ infection decreased during IFN treatment and increased again after treatment. Various investigators have reported a high prevalence of oral Candida species in patients with SS, compared to healthy controls [44-46].

Japanese $\mathrm{HCV}$-infected patients tend to be older than those in other countries and their older age favors the onset of HCC. In addition, oral candidiasis is underdiagnosed among the elderly [19]. Therefore, we require careful attention to the oral cavities of patients who receive IFN therapy.

\section{Conclusion}

In conclusion, our data show that IFN therapy led to the development of oral mucosal lesions, leading to oral candidiasis, and inhibited salivary secretion. We should pay more attention to oral candidiasis as well as additional oral mucosal lesions, in patients with weight loss during IFN treatment. Patients with $\mathrm{HCV}$ infection emphasize the paramount importance of oral management.

\section{Abbreviations \\ HCV: Hepatitis C virus; CH-C: Chronic hepatitis C; LC-C: Liver cirrhosis type C; HCC: Hepatocellular carcinoma; IFN: Interferon; RBV: Ribavirin; SVR: Sustained virological response; PLT: Platelets; Hb: Hemoglobin; ALT: Alanine aminotransferase; AST: Aspartate aminotransferase; LDH: Lactate dehydrogenase; T.Bil: Total bilirubin; Alb: Albumin.}

\section{Competing interests}

The authors declare that they have no competing interests.

\section{Authors' contributions}

YN carried out most of the data collection and drafted the manuscript. $\mathrm{KH}$ cultured Candida. MS contributed to data analysis. All authors read and approved the final manuscript.

\section{Acknowledgements}

This study was supported in part by a Grant-in-Aid for Scientific Research (C) (No.22592354) from the Ministry of Education, Culture, Sports, Science and Technology of Japan and supported in part by Health and Labour Sciences Research Grants for Research on Hepatitis from the Ministry of Health, Labour and Welfare of Japan.

\section{Author details}

${ }^{1}$ Department of Digestive Disease Information \& Research, Kurume University School of Medicine, 67 Asahi-machi, Kurume, Fukuoka 830-0011, Japan. ${ }^{2}$ Department of Laboratory Medicine, Kurume University Hospital, Kurume, Fukuoka 830-0011, Japan. 3Division of Gastroenterology, Department of Medicine, Kurume University School of Medicine, Kurume, Fukuoka 830-0011, Japan.

Received: 20 April 2012 Accepted: 31 October 2012

Published: 2 November 2012

\section{References}

1. Yoshida H, Shiratori $Y$, Moriyama M, Arakawa $Y$, Ide $T$, Sata M, Inoue O, Yano M, Tanaka M, Fujiyama S, Nishiguchi S, Kuroki T, Imazeki F, Yokosuka O, Kinoyama S, Yamada G, Omata M: Interferon therapy reduces the risk for hepatocellular carcinoma: national surveillance program of cirrhotic and noncirrhotic patients with chronic hepatitis C in Japan. IHIT Study Group. Inhibition of Hepatocarcinogenesis by Interferon Therapy. Ann Intern Med 1999, 131:174-181.

2. Yoshida H, Arakawa Y, Sata M, Nishiguchi S, Yano M, Fujiyama S, Yamada G, Yokosuka O, Shiratori Y, Omata M: Interferon therapy prolonged life expectancy among chronic hepatitis C patients. Gastroenterology 2002, 123:483-491.

3. Okanoue T, Itoh Y, Minami M, Sakamoto S, Yasui K, Sakamoto M, Nishioji K, Murakami Y, Kashima K: Interferon therapy lowers the rate of progression to hepatocellular carcinoma in chronic hepatitis $C$ but not significantly in an advanced stage: a retrospective study in 1148 patients. Viral Hepatitis Therapy Study Group. J Hepatol 1999, 30:653-659.

4. Mazzaferro V, Romito R, Schiavo M, Mariani L, Camerini T, Bhoori S, Capussotti L, Calise F, Pellicci R, Belli G, Tagger A, Colombo M, Bonino F, Majno P, Llovet JM, HCC Italian Task Force: Prevention of hepatocellular carcinoma recurrence with alpha-interferon after liver resection in HCV cirrhosis. Hepatology 2006, 44:1543-1554.

5. Chayama K, Hayes CN, Abe H, Miki D, Ochi H, Karino Y, Toyota J, Nakamura Y, Kamatani N, Sezaki H, Kobayashi M, Akuta N, Suzuki F, Kumada H: IL28B but not ITPA polymorphism is predictive of response to pegylated interferon, ribavirin, and telaprevir triple therapy in patients with genotype 1 hepatitis C. J Infect Dis 2011, 204:84-93.

6. McHutchison JG, Everson GT, Gordon SC, Jacobson IM, Sulkowski M Kauffman R, McNair L, Alam J, Muir AJ, PROVE1 Study Team: Telaprevir with peginterferon and ribavirin for chronic HCV genotype 1 infection. N Engl J Med 2009, 360:1827-1838. 
7. Gumber SC, Chopra S: Hepatitis C: A multifaceted disease. Review of extrahepatic manifestations. Ann Intern Med 1995, 123:615-620.

8. Pawlotsky JM, Ben Yahia M, Andre C, Voisin MC, Intrator L, Roudot-Thoraval F, Deforges L, Duvoux C, Zafrani ES, Duval J: Immunological disorders in C virus chronic active hepatitis: a prospective case-control study. Hepatology 1994, 19:841-848.

9. Cacoub P, Renou C, Rosenthal E, Cohen P, Loury I, Loustaud-Ratti V, Yamamoto AM, Camproux AC, Hausfater P, Musset L, Veyssier P, Raguin G, Piette JC: Extrahepatic manifestations associated with hepatitis $C$ virus infection. A prospective multicenter study of 321 patients. The GERMIVIC. Groupe d'Etude et de Recherche en Medecine Interne et Maladies Infectieuses sur le Virus de I'Hepatite C. Medicine (Baltimore) 2000, 79:47-56.

10. El-Serag HB, Hampel H, Yeh C, Rabeneck L: Extrahepatic manifestations of hepatitis C among United States male veterans. Hepatology 2002, 36:1439-1445

11. Jubert C, Pawlotsky JM, Pouget F, Andre C, DeForges L, Bretagne S, Mavier JP, Duval J, Revuz J, Dhumeaux D, Bagot M: Lichen planus and hepatitis C virus-related chronic active hepatitis. Arch Dermatol 1994, 130:73-76.

12. Nagao Y, Sata M, Tanikawa K, Itoh K, Kameyama T: Lichen planus and hepatitis $C$ virus in the northern Kyushu region of Japan. Eur J Clin Invest 1995, 25:910-914.

13. Carrozzo M, Gandolfo S, Carbone M, Colombatto P, Broccoletti R, GarzinoDemo $P$, Ghisetti $V$ : Hepatitis $C$ virus infection in Italian patients with oral lichen planus: a prospective case-control study. J Oral Pathol Med 1996, 25:527-533.

14. Bagán JV, Ramón C, González L, Diago M, Milián MA, Cors R, Lloria E, Cardona F, Jiménez Y: Preliminary investigation of the association of oral lichen planus and hepatitis C. Oral Surg Oral Med Oral Pathol Oral Radiol Endod 1998, 85:532-536.

15. Figueiredo LC, Carrilho FJ, de Andrage HF, Migliari DA: Oral lichen planus and hepatitis C virus infection. Oral Dis 2002, 8:42-46.

16. Carrozzo M: Oral diseases associated with hepatitis $C$ virus infection. Part 2: Lichen Planus and other diseases. Oral Dis 2008, 14:217-228.

17. Nagao Y, Sata M, Ide T, Suzuki H, Tanikawa K, Itoh K, Kameyama T: Development and exacerbation of oral lichen planus during and after interferon therapy for hepatitis C. Eur J Clin Invest 1996, 26:1171-1174.

18. Nagao Y, Sata M: Analysis of the factors motivating HCV-infected patients to accept interferon therapy. BMC Research Notes 2012, 5:470.

19. Akpan A, Morgan R: Oral candidiasis. Postgrad Med J 2002, 78:455-459.

20. Pankhurst CL: Candidiasis (oropharyngeal). Clin Evid 2006, 15:1849-1863.

21. Wilson J: The aetiology, diagnosis and management of denture stomatitis. Br Dent J 1998, 185:380-384.

22. Ellepola AN, Samaranayake LP: Antimycotic agents in oral candidosis: an overview: 1. Clinical variants. Dent Update 2000, 27:111-112. 114-116.

23. Soysa NS, Ellepola AN: The impact of cigarette/tobacco smoking on oral candidosis: an overview. The impact of cigarette/tobacco smoking on oral candidosis: an overview. Oral Dis 2005, 11:268-273.

24. Krogh P, Holmstrup P, Thorn JJ, Vedtofte P, Pindborg JJ: Yeast species and biotypes associated with oral leukoplakia and lichen planus. Oral Surg Oral Med Oral Pathol 1987, 63:48-54.

25. Jainkittivong A, Kuvatanasuchati J, Pipattanagovit P, Sinheng W: Candida in oral lichen planus patients undergoing topical steroid therapy. Oral Surg Oral Med Oral Pathol Oral Radiol Endod 2007, 104:61-66.

26. Cotler SJ, Wartelle CF, Larson AM, Gretch DR, Jensen DM, Carithers RL Jr: Pretreatment symptoms and dosing regimen predict side-effects of interferon therapy for hepatitis C. J Viral Hepat 2000, 7:211-217.

27. Aghemo A, Rumi MG, Monico S, Banderali M, Russo A, Ottaviani F, Vigano M, D'Ambrosio R, Colombo M: Ribavirin impairs salivary gland function during combination treatment with pegylated interferon alfa-2a in hepatitis C patients. Hepat Mon 2011, 11:918-924.

28. Nagao Y, Sata M: Dental problems delaying the initiation of interferon therapy for HCV-infected patients. Virol J 2010, 7:192

29. Lee SC, Antony A, Lee N, Leibow J, Yang JQ, Soviero S, Gutekunst K, Rosenstraus M: Improved version 2.0 qualitative and quantitative AMPLICOR reverse transcription-PCR tests for hepatitis $C$ virus RNA: calibration to international units, enhanced genotype reactivity, and performance characteristics. J Clin Microbiol 2000, 38:4171-4179.

30. Sizmann D, Boeck C, Boelter J, Fischer D, Miethke M, Nicolaus S, Zadak M, Babiel R: Fully automated quantification of hepatitis $C$ virus (HCV) RNA in human plasma and human serum by the COBAS AmpliPrep/COBAS TaqMan system. J Clin Virol 2007, 38:326-333.

31. Dusheiko G, Schmilovitz-Weiss H, Brown D, McOmish F, Yap PL, Sherlock S, Mclntyre N, Simmonds P: Hepatitis C virus genotypes: an investigation of type-specific differences in geographic origin and disease. Hepatology 1994, 19:13-18.

32. Zeng X, Hou X, Wang Z, Jiang L, Xiong C, Zhou M, Chen Q: Carriage rate and virulence attributes of oral Candida albicans isolates from patients with oral lichen planus: a study in an ethnic Chinese cohort. Mycoses 2009, 52:161-165.

33. Coates EA, Brennan D, Logan RM, Goss AN, Scopacasa B, Spencer AJ, Gorkic E: Hepatitis C infection and associated oral health problems. Aust Dent J 2000, 45:108-114.

34. Coates $E A$, Walsh $L$, Logan $R$ : The increasing problem of hepatitis $C$ virus infection. Aust Dent J 2001, 46:13-17.

35. Henderson L, Muir M, Mills PR, Spence E, Fox R, McCruden EA, Bagg J: Oral health of patients with hepatitis $C$ virus infection: a pilot study. Oral Dis 2001, 7:271-275

36. Griffin SO, Barker LK, Griffin PM, Cleveland JL, Kohn W: Oral health needs among adults in the United States with chronic diseases. J Am Dent Assoc 2009, 140:1266-1274.

37. Komaki N, Watanabe T, Ogasawara A, Sato N, Mikami T, Matsumoto T: Antifungal mechanism of hinokitiol against Candida albicans. Biol Pharm Bull 2008, 31:735-737.

38. Nagao $Y$, Michio S: Effect of oral care gel on the quality of life for oral lichen planus in patients with chronic HCV infection. Virol J 2011, 8:348.

39. Back-Brito GN, da Mota AJ, de Souza Bernardes LÂA, Takamune SS, Prado Ede F, Cordás TA, Balducci I, da Nobrega FG, Koga-lto CY: Effects of eating disorders on oral fungal diversity. Oral Surg Oral Med Oral Pathol Oral Radiol 2012, 113:512-517.

40. Nagao $Y$, Sata M: Serum albumin and mortality risk in a hyperendemic area of HCV infection in Japan. Virol J 2010, 7:375.

41. Nagao $Y$, Sata M: A retrospective case-control study of hepatitis $C$ virus infection and oral lichen planus in Japan: association study with mutations in the core and NS5A region of hepatitis $C$ virus. BMC Gastroenterol 2012, 12:31.

42. Nagao $Y$, Hanada S, Shishido $S$, Ide T, Kumashiro R, Ueno T, Sata M: Incidence of Sjögren's syndrome in Japanese patients with hepatitis C virus infection. J Gastroenterol Hepatol 2003, 18:258-266.

43. Carrozzo M: Oral diseases associated with hepatitis $C$ virus infection. Part 1. sialadenitis and salivary glands lymphoma. Oral Dis 2008, 14:123-130.

44. Scully C, El-Kabir M, Samaranayake LP: Candida and oral candidosis: a review. Crit Rev Oral Biol Med 1994, 5:125-157.

45. Järvensivu A, Hietanen J, Rautemaa R, Sorsa T, Richardson M: Candida yeasts in chronic periodontitis tissues and subgingival microbial biofilms in vivo. Oral Dis 2004, 10:106-112.

46. Ergun S, Cekici A, Topcuoglu N, Migliari DA, Külekçi G, Tanyeri H, Isik G: Oral status and Candida colonization in patients with Sjögren's Syndrome. Med Oral Patol Oral Cir Bucal 2010, 15:e310-e315.

\section{doi:10.1186/1471-230X-12-155}

Cite this article as: Nagao et al:: Candidiasis and other oral mucosal lesions during and after interferon therapy for HCV-related chronic liver diseases. BMC Gastroenterology 2012 12:155.

\section{Submit your next manuscript to BioMed Central and take full advantage of:}

- Convenient online submission

- Thorough peer review

- No space constraints or color figure charges

- Immediate publication on acceptance

- Inclusion in PubMed, CAS, Scopus and Google Scholar

- Research which is freely available for redistribution 